\title{
Ústavní hodnoty a autonomie vůle v právním jednání v soukromém právu*
}

\section{Constitutional Values and Autonomy of the Will in Legal Transactions in Private Law}

\author{
Pavel Ondřejek ${ }^{* *}$
}

\begin{abstract}
Abstrakt
Clánek analyzuje horizontálni pisobení základnich práv na základè strukturálni analýzy souboru hodnot a systémových, própadně protisystémových elementů v právu. Dotýká se tak relevance dichotomie soukromé-

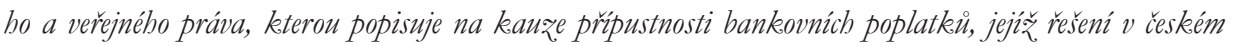
a nèmeckém právu se podstatně lišilo. Prijmeme-li jako východisko ústredni roli právnich principu a hodnot

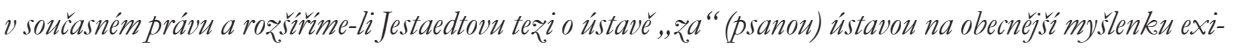
stence práva v podobè nepsaných normativních standardù na pozadí psanébo práva, pak. naznačený konflikt mezi smluvni autonomii a základními právy je nutné vnimat šireji: nejen jako konfliket pozitivnèprávnich úprav v ústavě a zákonech soukromébo práva, ale i fundamentálnich zásad a hodnot v obou téchto právnich odvétvich.
\end{abstract}

\section{Klíčová slova}

právni jednáni; hodnoty v právu; poměrování; horizontálni úcinky základnich práv; právnická osoba.

\section{Abstract}

The article analyses horizontal effects of fundamental rights on the basis of structural analysis of set of values and systemic or antisystemic elements in law. In the article, the relevance of a dichotomy of private and public law is discussed on the example of cases concerning the lawfulness of bank fees (where Czech and German courts reached different solution). If we accept as a starting point crucial role of legal principles and values in contemporary law and if we broaden Jestaedt's thesis about constitution "beyond" the (written) constitution on more general thesis about the existence of law (in the form of unwritten normative standards) beyond written law, then the conflict between contractual autonomy and fundamental rights needs to be understood in a broader way: not only as a conflict between positive legal regulations in the constitution and laws in private law, but also between fundamental principles and values in both of these branches of law.

\section{Keywords}

Legal Transaction; Values in Law, Balancing; Horizontal Effects of Fundamental Rights; Juristic Person.

* Př́spěvek vznikl v rámci plnění projektu Grantové agentury ČR reg. č. 16-22016S „Právní jednání a odpovědnost právnických osob“. Poděkování patř́i J. Brozovi, Z. Červínkovi, V. Janečkovi, M. Káčerovi, J. Kyselovi, J. Ondřejkové, M. Tomoszkovi a J. Wintrovi, s nimiž jsem mohl diskutovat některé myšlenky obsažené v tomto článku, at’ již v průběhu Weyrových dnů právní teorie v červnu 2016 nebo jinde. Za komentáře $\mathrm{k}$ textu děkuji i dvěma anonymním recenzentům.

** JUDr. Pavel Ondřejek, Ph.D., Katedra teorie práva a právních učení, Právnická fakulta, Univerzita Karlova, Praha / Department of Legal Theory and Legal Doctrines, Faculty of Law, Charles University, Prague, Czech Republic / E-mail: ondrejek@prf.cuni.cz 
V červnu roku 2011 rozhodl německý Spolkový nejvyšší soud o neprrípustnosti klauzulí, týkajících se poplatků za správu a vedení úvěrových účtů, obsažených v obchodních podmínkách bank. ${ }^{1}$ Tímto rozhodnutím otevřel zajímavou debatu o limitech autonomie vůle v soukromoprávních vztazích. Hlavní argument Spolkového nejvyššího soudu spočíval v rozlišení hlavních a vedlejších ujednání o ceně s tím, že pokud je cena protiplnění součástí hlavního ujednání, je takovýto přezkum ceny podle právních předpisů evropských i vnitrostátních vyloučen. Jedná se o logickou úpravu, nebot’ stanovení ceny je věcí konsenzu stran a úlohou soudu nemůže být tuto dohodu nahrazovat. V daném případě však německý nejvyšší soud bankovní poplatky hodnotil jako vedlejší cenová ujednání, jimž neodpovídá žádné protiplnění ze strany bank. Podle soudu jde o ujednání, jež v rozporu s př́kazem dobré víry nepřiměřeně poškozují spotřebitele. Rozhodnutí Spolkového nejvyššího soudu vyvolalo značné kontroverze; podle mnohých kritiků je totiž sporné rozlišovat dva druhy cenových ujednání, ${ }^{2}$ namísto toho je třeba poplatky vnímat jako součást celkové „,ceny“ bankovní služby. ${ }^{3}$

Záhy po zmíněném německém rozhodnutí byla v České republice zahájena kampaň, mající za cíl zapojit větší množství osob do žalob proti bankám účtujícím identické poplatky v České republice. Několik souběžných iniciativ bylo úspěšných, podle dostupných zdrojů podalo v polovině roku 2013 žalobu více než 300.000 klientů bank. ${ }^{4}$ Hlavní argumenty zastánců zrušení bankovních poplatků za správu a vedení úvěrových účtů v České republice byla přenositelnost argumentů Spolkového nejvyššího soudu kvưli podobnosti právní úpravy, která v obou státech vycházela z evropské směrnice o nepřiměřených podmínkách ve spotřebitelských smlouvách. ${ }^{5}$ Přes obdobný základ obou prrípadů však dopadla řízení v České republice a v Německu odlišně. Zatímco v Německu o kauze rozhodoval v poslední instanci Spolkový nejvyšší soud a celá argumentace na linii obecných soudů se odehrávala na pozadí diskusí o aplikovatelných soukromoprávních zásadách, v České republice kauzy opravným řízením neprošly, a to z důvodu, že se v jejich př́ipadech jednalo o bagatelní žalované částky (bankovní poplatky dosahovaly výše okolo 150 Kč měsíčně). Rozhodnutí soudů první instance v České republice o př́pustnosti

1 Rozhodnutí IX. Senátu BGH ze dne 7.6.2011, sp. zn. IX ZR 388/10.

2 FRANK, Rainer, VESELKOVÁ, Pavla, WOLF, Patrick. Přípustnost poplatků za správu a vedení úvěrových účtů vedených pro spotřebitele. Pránni roẓledy. 2013, č. 12-13, s. 515. Autoři ve svém článku zmiňujî především německou literaturu, která se závěry rozhodnutí Spolkového nejvyššího soudu polemizuje.

3 Ostatně stejně vnímal bankovní poplatky v obdobném rozhodnutí ve Velké Británii tamější Nejvyšší soud, srov. rozhodnutí (mimochodem jedno z prvních po jeho vzniku) Office of Fair Trading v. Abbey National plc \& Others ze dne 25. 11. 2009, [2009] UKSC 6.

4 FRANK, Rainer, VESELKOVÁ, Pavla, WOLF, Patrick, op. cit., s. 515. K množství žalob přispěla zřejmě i přetrvávající nespokojenost s výší poplatků, které klienti v České republice bankám odvádějí. Např́íklad každoroční anketa o nejabsurdnější bankovní poplatek serveru www.bankovnipoplatky.com získává pravidelně velkou pozornost ve většině hlavních médií.

5 Směrnice Rady č. 93/13/EHS. 
bankovních poplatků nebyla jednotná, a tak se v této věci čekalo na verdikt Ústavního soudu, který následně de facto sjednotil judikaturu obecných soudů. ${ }^{6}$

V řízení před českým Ústavním soudem se navrhovatelé snažili dát př́ípadu potřebný ústavní rozměr tvrzením o nutnosti podřazení ochrany spotřebitele ${ }^{7}$ pod ústavní princip rovnosti v materiálním smyslu a korigováním autonomie vưle ,principem ekvity či spravedlnosti. “8 Přestože Ústavní soud, jak známo, tento argument nepřijal a ve svém odůvodnění v zásadě i zpochybnil ústavní rozměr celé kauzy, je podle mého názoru důležité poukázat na rozdílné argumenty používané v České republice a Německu. V německé kauze byla argumentační linie vedena výlučně instituty a doktrínami občanského práva, v českém př́padě byly do této primárně soukromoprávní kauzy vneseny argumenty ústavních principů a hodnot. ${ }^{9}$

Pod označením „horizontální účinky základních práv“ nalezneme v současné právní doktríně celou řadu teorií. Podle relevance různých faktorů popisují autoři prrímé nebo nepřímé působení, anebo působení skrze judikaturu soudů. ${ }^{10}$ Jednotlivé modely horizontálního působení základních práv je podle mého názoru třeba promýšlet, nikoliv mechanicky aplikovat pravidlo o přednosti ústavních norem, principů a hodnot. Takto je, myslím, nezbytné rozumět pravidlu v \ 2 zákona č. 89/2012 Sb., občanského zákoníku (v dalším textu jen „občanský zákoník“), podle něhož „,[k]aždé ustanovení soukromého práva lze vykládat jenom ve shodě s Listinou základních práv a svobod a ústavním porádkem vůbec $[\ldots]]^{\text {“. }}{ }^{11}$ Hlavním cílem příspěvku bude proto nastínit možné problémy

6 Nález Ústavního soudu sp. zn. III. ÚS 3725/13 ze dne 10. 4. 2014 (bankovní poplatky).

$7 \mathrm{~K}$ pojmu spotřebitele v soukromém právu viz např. ELISCHER, D. Spotřebitel. In: DVOŘÁK, J., ŠVESTKA, J., ZUKLÍNOVÁ, M. a kol. Občanské právo bmotné 1. Díl proní: Obecná část. 2. aktualizované a doplněné vydání. Praha: Wolters Kluwer, 2016, s. 290 a násl.

8 Nález Ústavního soudu sp. zn. III. ÚS 3725/13, odst. 7 odůvodnění nálezu. Nutno však konstatovat, že v návaznosti na argumentaci Ústavním soudem se zdá, že ústavní dimenze celého př́padu nebyla př́liš podrobně vyargumentována. Navrhovatelé se nemohli opř́í o inspiraci ze Spolkové republiky Německo, nebot' př́pad se před Spolkový ústavní soud nedostal.

9 Na straně jedné lze souhlasit s tvrzením, že není nic nezvyklého na tom, že ústavní soudy argumentují ústavním právem a soudy obecné justice zákony. V př́padě obecných soudů je však třeba trvat na tom, aby nebyly opomíjeny ústavní rozměry prrípadu. Pokud by totiž nebyly vzaty v potaz, staly by se ústavní soudy univerzální superrevizní instancí, což je role, které se brání.

10 S určitým zjednodušením lze za přímý horizontální účinek označit model, kdy se jednotlivci v soukromoprávních sporech mohou dovolávat základních práv přímo proti jiným subjektům soukromého práva; nepřímý účinek je pak charakteristický pronikáním ústavních práv skrze interpretaci neurčitých právních pojmů v soukromém právu, jakými jsou např. dobré mravy nebo dobrá víra. Působení skrze soudní judikaturu se od předchozích modelů liší tím, že vylučuje jakékoliv působení mezi soukromými subjekty, avšak za státní orgán, který je povinen poskytovat ochranu základním právům, je považován i soud, který rozhoduje soukromoprávní spor. Ten pak musí zohlednit fakt, aby svým rozsudkem v žádném př́padě neporušil základní právo jakékoli strany sporu. V podrobnostech viz BARAK, Aharon. Constitutional Human Rights and Private Law. In: FRIEDMAN, Daniel, BARAK-EREZ, Daphne (eds.). Human Rights in Private Law. Oxford, Portland: Hart Publishing, 2001, s. 13 a násl.

11 Srov. v tomto smyslu důvodovou zprávu k občanskému zákoníku dostupnou na stránkách: http://obcanskyzakonik.justice.cz/images/pdf/Duvodova-zprava-NOZ-konsolidovana-verze.pdf [cit. 20.6.2016], s. 33. 
horizontálního působení, a to na abstraktnější úrovni kolizí principů a hodnot v ústavním a soukromém právu. ${ }^{12}$

\section{Hodnoty a principy jako fundament ústavního i soukromého práva}

Zdůrazňování role nepsaných právních principů a hodnot na pozadí práva je typické zejména pro nonpozitivistické právní myšlení. Z modernějších teorií lze poukázat na Alexyho duální charakter práva, jež obsahuje dimenzi ideální a kritickou, a zároveň reálnou či faktickou. ${ }^{13}$ Ideální rozměr práva se nejvíce projevuje v Alexyho tezi o nároku na správnost (Anspruch an Richtigkeit, claim to correctness) v právu i jeho interpretaci. ${ }^{14}$ Úloha právních principů a hodnot však v současné právní doktríně není spojena výlučně s nonpozitivistickým pojetím práva. Níže se pokusím nastínit několik koncepcí, osvětlujících roli principů a hodnot v ústavním právu.

Americký ústavní teoretik Larry Alexander označuje ústavu za instrument sloužící k překonávání rozporů mezi individuálními preferencemi ohledně společenského uspořádání. K popisu svých argumentů používá následující model. Ideálně má každý jednotlivec určitou představu o tom, jak má být vykonávána veřejná moc ve společnosti. Tyto názory se však mohou lišit. Hlavní funkcí ústav je tak nalezení dohody politického společenství na fundamentálních otázkách, a to za pomoci systému základních pravidel, jakými jsou např. rozhodování většinovým hlasováním, anebo pravidlo existence soudů chránících individuální práva. ${ }^{15}$

Klíčovou otázkou, kterou L. Alexander dále rozvíjí, pak je, zdali se přijetí ústavy týká pouze dohody o samotném textu, který ústavodárce prrijal, anebo jsou spolu s ním přijímány i navazující doktríny a principy, které jsou tradičně spojovány s výrazy, použitými v zákoně. L. Alexander argumentuje ve prospěch posléze uvedené teze, když tvrdí, že dohodou na ústavě přijímáme více než jen systém jednoduchých pravidel, akceptujeme totiž zároveň i další pravidla o pravomoci rozhodovat př́padné spory a zejména o způsobu výkladu. Posléze uvedená pravidla tvoří v jeho terminologii meta-ústavu, ${ }^{16}$ jejíž součástí jsou i základní principy a dále hodnoty, na nichž je ústava založena, nebot' právě ty určují, jak přistupovat k složitým interpretačním případům. Rozlišováním ústav

12 Kontradiktorní charakter principů a hodnot bude vzhledem k abstraktnějšímu charakteru těchto standardů do značné míry záviset na naší interpretaci jejich vzájemného vztahu. Konflikt totiž např́iklad můžeme označit toliko za zdánlivý.

13 ALEXY, Robert. The Dual Nature of Law. Ratio Juris. 2010, roč. 23, č. 2, s. 167.

$14 \mathrm{~K}$ těmto tezím podrobněji v díle: ALEXY, Robert. Pojem a platnost práva. Bratislava: Kalligram, 2009 , s. 60 a násl. Přehledově v kontextu celého Alexyho díla pak KLATT, Matthias. Robert Alexy's Philosophy of Law as System. In: KLATT, Matthias (ed.). Institutionalized Reason. The Jurisprudence of Robert Alexy. Oxford: Oxford University Press, 2012, s. 15-16.

15 ALEXANDER, Larry. Constitutionalism. In: GOLDING, Martin P., EDMUNDSON, William (eds.). The Blackwell Guide to the Philosophy of Law and Legal Theory. Malden: Blackwell Publishing, 2006, s. 248-249. Tato sada abstraktních pravidel naznačuje: kdo, kdy a o čem ve státě rozhoduje.

16 ALEXANDER, Larry. op. cit., s. 250. 
a meta-ústav lze vysvětlit, jak se liší změny ústavy (kdy se mění platné ústavní právo, nikoliv fundamentální hodnoty) od ústavních revolucí, v nichž dochází k proměně meta-ústavy, a tím i hodnotové orientace. ${ }^{17}$ Úvahy o existenci meta-ústavy jsou podle mého názoru významné i pro konstruování dalších ústavních doktrín, například materiálního jádra ústavy či ústavní identity. ${ }^{18}$

Význam ústavních hodnot a dalších součástí ústavního práva při interpretaci ústavy lze ukázat na př́kladu poměřování základních práv a svobod, tj. jedné ze složek principu proporcionality v ústavním právu. Jedním z často diskutovaných témat v souvislosti s poměřováním a proporcionalitou je univerzalita těchto argumentačních metod, tedy totožnost a stejná struktura principu proporcionality ve všech právních řádech. Autoři zastávající toto pojetí argumentují univerzální racionalitou tohoto př́stupu, ${ }^{19}$ kritikové si naopak všímají pouze zdánlivé jednoty v prrístupech jednotlivých států. ${ }^{20}$ Přes tyto rozdíly panuje v odborné literatuře shoda, že pro řešení konkrétního případu je potřeba argumentovat vždy konkrétními ústavními principy a hodnotami, které se daného př́padu dotýkaji. ${ }^{21}$ Přestože je v různých státech aplikována víceméně podobná forma tohoto testu, konkrétní řešení se může odvíjet nap̌r. od ústředního postavení lidské důstojnosti v německém ústavním právu, potvrzovaného opakovaně judikaturou Spolkového ústavního soudu. ${ }^{22}$

17 ALEXANDER, Larry. op. cit., s. 250.

18 Podobnou úvahu o pozadí ústavního práva rozvíî́ M. Jestaedt rozlišující velkou ústavu (constitutio maior), obsahující její ideový, metafyzický a hodnotový základ, a malou ústavu (constitutio minor), vytvářející jevovou formu ústavní dogmatiky. $\mathrm{K}$ této teorii v české literatuře viz KYSELA, Jan. Ústava mez̧i právem a politikou. Praha: Leges, 2014, s. 35 odkazující na publikaci JESTAEDT, Matthias. Die Verfassung hinter der Verfassung: Eine Standortbestimmung der Verfassungstheorie. Paderborn, München, Wien, Zürich: Ferdinand Schöningh, 2009, zejm. s. 45 a násl. Právě členění na ústavní teorii a ústavní dogmatiku je podle M. Jestaedta důležité rozlišovat proto, aby nebyla ústava proměňována pouhou interpretací.

19 ALEXY, Robert. Constitutional Rights, Balancing and Rationality. Ratio Juris, 2003, roč. 16, č. 2, s. 135 a násl. K univerzálnímu charakteru Alexyho teorií srov. též: MENÉNDÉZ, José Agustín, ERIKSEN, Erik Oddvar. Introduction. In: MENÉNDÉZ, José Agustín, ERIKSEN, Erik Oddvar (eds.). Arguing Fundamental Rights. Dordrecht: Springer, 2006, s. 4.

20 Zastáncem odlišného pojetí poměřování v závislosti na právních systémech je J. Bomhoff - BOMHOFF, Jacco. Balancing Constitutional Rights. The Origins and Meanings of Postwar Legal Discourse. Cambridge: Cambridge University Press, 2014, s. 239. Podrobněji viz i BOMHOFF, Jacco. Balancing, the Global and the Local: Judicial Balancing as a Problematic Topic in Comparative (Constitutional) Law. Hastings International and Comparative Law Review. 2008, s. 584 a násl.

21 Ilustrativně na to poukazuje J. Wintr na příkladech použití Alexyho vážící formule na vybrané kauzy českého Ústavního soudu: WINTR, Jan. Alexyho vážící formule. Právník. 2016, č. 5, s. 446-461.

22 Ke sporům ohledně absolutní a relativní podoby lidské důstojnosti srov. BARAK, Aharon. Human Dignity. The Constitutional Value and the Constitutional Right. Cambridge: Cambridge University Press, 2015, s. 227-228. Relativní charakter lidské důstojnosti, který je v německé literatuře stále menšinovým názorem, představil nedávno i v české odborné literatuře R. Alexy: srov. jeho článek ALEXY, Robert. Lidská důstojnost a princip proporcionality. Právník. 2015, č. 11, s. 867 a násl. Zastánci absolutní povahy lidské důstojnosti prrirozeně odmítají jakékoliv poměřování, protože podle jejich pojetí nelze lidskou důstojnost omezit ústavně konformním způsobem. K absolutní povaze lidské důstojnosti viz i závěry německého Spolkového ústavního soudu ve věci protiústavnosti ustanovení zákona o bezpečnosti letectví, jež umožňovalo sestřelit unesené letadlo (Luftsicherheitsgesetz - rozhodnutí ze dne 15. února 2006, BVerfGE 115, 118). 
Ústavní právo se již od počátku vyvijelo jako právo regulující vztah jednotlivce k veřejné moci. Soukromé právo naproti tomu vychází z odlišných východisek, kterými je potřeba nastavit regulaci jednání subjektů mezi sebou při úpravě vztahů vyplývajících zejména ze smluv, soukromoprávních deliktů a majetkových vztahů. Odlišnému cíli odpovídají i různé principy. ${ }^{23}$ Právě pozoruhodná kontinuita soukromého práva (v př́padě států kontinentální právní kultury dokonce s tradicemi antického Říma) ukazuje, že podobně jako za ústavními texty stojí fundament v podobě principů a hodnot, na nichž je ústava založena, nalezneme i v soukromém právu základ v podobě principů a hodnot, vyvěrající z ještě starších tradic. Bylo to ostatně soukromé právo, které na evropském kontinentu částečně plnilo funkci ústav před jejich formálním přijetím. ${ }^{24}$

Př́kladem v soukromém právu mohou být teorie kontraktu, reflektující právní závaznost učiněného slibu či vzájemné dohody. ${ }^{25}$ Neexistuje však jednotná teorie, spíše množství př́stupo̊, např́iklad v dnešní době moderní ekonomická analýza práva, ${ }^{26}$ anebo právně realistické prrístupy zpochybňujících tezi o apolitickém charakteru rozhodování soudů v civilním řízení, které by bylo nezávislé na jakémkoliv pojetí veřejných dober. ${ }^{27} \mathrm{~V}$ krajním př́ipadě lze dokonce hovořit o úplném smazání rozdílů mezi soukromým a veřejným právem. Proti tomuto př́stupu však lze spolu s B. Zipurskym namítnout, že přestože dochází k prolínání soukromého a veřejného práva, úlohy státu v soukromém právu na straně jedné a ve veřejném právu na straně druhé se podstatně liší. Základem sou-

$23 \mathrm{~K}$ argumentaci ve prospěch rozlišování soukromoprávních a veřejnoprávních principů viz též WINTR, Jan. Rišse principu. Obecné a odvětvové principy soǔasnébo českébo práva. Praha: Karolinum, 2006, s. 62-63. Soukromoprávní zásady jsou v české odborné literatuře tématem několika studií J. Hurdíka - HURDÍK, Jan. Zásady soukromého práva. Brno: Masarykova univerzita, 1998; HURDÍK, Jan, LAVICKÝ, Petr. Systém zásad soukromého práva. Brno: Masarykova univerzita, 2010. Ze zahraničních studií srovnávajících různé právní systémy viz ZIPURSKY, Benjamin. Philosophy of Private Law. In: COLEMAN, Jules, SHAPIRO, Scott (eds.). The Oxford Handbook on Jurisprudence and Philosophy of Law. Oxford: Oxford University Press, 2002, s. 653. COLLINS, Hugh. On the (In)compatibility of Human Rights Discourse and Private Law. In: MICKLITZ, Hans-W. (ed.). Constitutionalization of European Private Law. Oxford: Oxford University Press, 2014, s. 28.

24 Srov. první kodexy občanského práva z přelomu 18. a 19. století. Podle K. Adamové: „v ABGB nalézáme prvky ústavněprávní a odraz teorie nezcizitelných a nezadatelných občanských práv. [...] Občanský zákoník vychází z premisy, že každý má vrozená, samým rozumem seznatelná práva[...] ABGB tedy znamenal kompromis mezi existujícím politickým systémem a požadavky rozvíjejícího se liberalismu. “ Viz ADAMOVÁ, Karolína. Občanská práva a svobody v rakouských ústavách 19. století. In: MALÝ, Karel, SOUKUP, Ladislav (eds.). Vývoj české ústavnosti v letech 1618 - 1918. Praha: Karolinum, 2006, s. 423.

25 POSNER, Eric A. Contract Theory. In: GOLDING, Martin P., EDMUNDSON, William A. (eds.). The Blackwell Guide to the Philosopby of Law and Legal Theory. Malden: Blackwell Publishing, 2005, s. 138. Podrobněji k závaznosti slibu v právních jednáních viz RAZ, Joseph. Promises in Morality and Law. Book Review: Atiyah P., S. Promises, Morals, Law. Oxford: Clarendon Press, 1981. Harvard Law Review. 1982, roč. 95 , č. 3, s. 928.

26 POSNER, Eric A. op. cit., s. 138-140.

27 ZIPURSKY, Benjamin. op. cit., s. 653. 
kromého práva je regulace vzájemných práv a povinností osob. ${ }^{28}$ Stát měl tedy primárně umožnit jednotlivcům určitým způsobem postupovat vưči jiným jednotlivcům ${ }^{29}$ a za tím účelem by měl např́iklad autoritativně potvrzovat, který z jednotlivců nedodržel smlouvu anebo kdo způsobil škodu zásahem do absolutního subjektivního práva.

$\mathrm{V}$ úvodu zmiňovaný prŕklad bankovních poplatků odkazoval ve vícero státech, v nichž se obdobná kauza vyskytla, k nutnosti vyřešit konflikt několika hodnot, jichž se týkal. $\mathrm{Na}$ straně jedné šlo o autonomii vưle, $\mathrm{v}$ daném případě smluvní svobodu, na straně druhé zde hrály roli důsledky plynoucí z faktické nerovnosti smluvních stran. ${ }^{30} \mathrm{Od}$ tvrzené nerovnosti spojené s vnucením obsahu smlouvy je již pouze malý krok k ochraně hodnoty lidské důstojnosti i v soukromoprávních vztazích. ${ }^{31}$ Argumenty založené na autonomii odmítají zasahovat do smluvního vztahu, do něhož oba subjekty vstoupily dobrovolně. Naproti tomu argumenty materiální rovností poukazují na to, že právo by mělo chránit slabší stranu ${ }^{32}$ a prosazovat tím „spravedlivějšsi““ soukromé právo. ${ }^{33}$

$\mathrm{V}$ další části bych chtěl analyzovat možné prŕístupy $\mathrm{k}$ řešení tohoto případu, $\mathrm{v}$ němž šlo primárně o platnost právního jednání. Na pozadí konkrétní právní úpravy je však možné analyzovat konflikt hodnot a právních principů. Analýza struktury právního řádu a systému hodnot vyskytujících se na jeho pozadí bude proto představovat východisko pro nástin modelů horizontálních účinků základních práv.

\section{Strukturální přístup k řešení hodnotových kolizí při horizontálním působení základních práv}

Horizontální účinky lidských práv jsou na první pohled spojeny s určitým napětím mezi skupinami norem, principů a hodnot majících původ v soukromém a ústavním právu. ${ }^{34}$

28 Srov. \1 odst. 1 zák. č. 89/2012 Sb., občanského zákoníku.

29 ZIPURSKY, Benjamin. op. cit., s. 655.

30 K oběma těmto zásadám podrobněji: HURDÍK, Jan, LAVICKÝ, Petr: op. cit., s. 82 a násl.

31 Lidská důstojnost je pojem, jehož obsah utvářen interpretací. Současný trend, který však budí jisté pochybnosti, je spíše širší výklad. K různým aspektům argumentace lidskou důstojností soudy srov. HAPLA, Martin. Důstojnost a lidská práva: užitečné spojení, nebo účelová fráze? In: VEČEŘA, Miloš, STACHOŇOVÁ, Monika, HAPLA, Martin (eds.). Weyrưv den právni teorie. Sborník př̌spèvkè z konference. Brno: Masarykova univerzita, 2015, s. 25 a násl., ŠIMÁČKOVÁ, Kateřina. Ostych před důstojností jako právním pojmem anebo kdy se soudce bez důstojnosti neobejde? In: VEČĚ̌A, Miloš, STACHOŇNOV́, Monika, HAPLA, Martin (eds.). Weyruiv den právni teorie. Sbornike př̌spèvkè z konference. Brno: Masarykova univerzita, 2015, s. 10 a násl.

32 HURDÍK, Jan, LAVICKÝ, Petr: op. cit., s. 95. „Možnost svobodného jednání je součástí právního statusu každého člověka[...] Takový přístup může fungovat pouze při regulaci vztahů, v nichž proti sobě stojí osoby, jež [...] disponují také reálně přibližně stejnými vyjednávacími pozicemi.“"

33 MICKLITZ, Hans-W. Introduction. In: MICKLITZ, Hans-W. (ed.). Constitutionalisation of European Private Law. Oxford: Oxford University Press, 2014, s. 1.

34 Právě z důvodu orientace na téma horizontálních účinků základních práv se budu věnovat výlučně konfliktům soukromoprávních a ústavněprávních norem, principů a hodnot, tím samozrejmě nepopírám existenci jiných kolizí principo̊ a hodnot, například v rámci jednotlivých odvětví. 
Vzhledem ke komplexitě pravidel, která do řešení případu vstupují, navrhuji pro popis modelu horizontálního působení zvažovat nezávisle dvě proměnné: systematiku hodnot a systematiku práva. Na straně jedné lze sice souhlasit s tím, že mezi právem a hodnotami existují četné souvislosti, např́klad jsou to právě lidská práva, jež bývají považována za projev nejvýznamnějších hodnot uznávaných společností. ${ }^{35} \mathrm{Na}$ druhé straně však podle mého názoru samostatné zkoumání struktury práva a systému hodnot lépe umožňuje popsat důsledky pro horizontální působení základních práv. Východiskem dalších úvah bude tedy systémové hodnocení práva a hodnot. Jak právo, tak hodnoty se mohou ideálně nacházet ve vztahu řádu, hierarchie a jednoty anebo plurality, heterarchie a diferenciace. ${ }^{36}$

Na úrovni hodnot se uvedená diferenciace projevuje v otázce, zda se právní systém upírá $\mathrm{k}$ jediné nejvyšší hodnotě, anebo se právo hlásí $\mathrm{k}$ mnoha hodnotám, z nichž žádnou nepreferuje jako absolutní. Tyto stavy budu nazývat hierarchickým a nehierarchickým uspořádáním hodnot. ${ }^{37}$ Oba tyto modely mohou uznávat vícero hodnot, rozdíl je v tom, zda je určitá hodnota vnímaná jako nejvyšší anebo se nacházíme ve stavu popisovaném jako rozumná neshoda, ${ }^{38} \mathrm{kdy}$ diskurz o vztahu jednotlivých hodnot nevede ke konsenzu ohledně toho, že by jedna z nich měla převažovat.

$\mathrm{Na}$ úrovni uvažování o systému práva se obdobná diferenciace projevuje v tom, jak v právu působí různé systémové a protisystémové elementy. $\mathrm{K}$ systémovým prvkům patři např́klad univerzální právní principy plnící jednotící funkci, ${ }^{39}$ anebo hierarchické uspořádání soudní soustavy, v níž může existovat jeden nejvyšší soud (jako je tomu $\mathrm{v}$ americkém právním systému). K protisystémovým elementům lze zařadit naopak existenci několika nejvyšších soudů pro specifické oblasti práva (jako je tomu např́íklad v Německu anebo v České republice). ${ }^{40}$ Podle míry převažujících prvků může právní systém tendovat $\mathrm{k}$ posilování jednoty anebo naopak diferenciace. ${ }^{41}$

35 MARŠÁLEK, Pavel. Právo a společnost. Praha: Auditorium, 2008, s. 111.

36 Mưže být namítáno, že právo je vystaveno na určitém ideálu vnitřní jednoty, tíhne tedy k jednotě a brání se diferenciaci. Naproti tomu však lze v akademickém diskurzu sledovat různé vlivy oslabování jednoty až fragmentace práva ( $k$ jednotlivým prííladům viz níže).

37 Tyto termíny k popisu mé koncepce navrhl použít J. Wintr. Ještě jednou mu proto děkuji za ochotu konzultovat se mnou obsah článku.

38 Anglicky „reasonable disagreement“ - $\mathrm{k}$ tomuto pojmu podrobněji viz SOBEK, Tomáš. Práuní myšlení. Kritika moralismu. Plzeň - Praha: Aleš Čeněk, Ústav státu a práva AV ČR, 2011, s. 84.

39 GERLOCH, Aleš. Teorie práva. 6. vyd., Plzeň: Aleš Čeněk, 2013, s. 115.

40 RÖHL, Klaus, RÖHL, Hans Christian. Allgemeine Rechtslebre, 3. vyd., Köln: Carl Heymanns Verlag, 2008, s. 453.

41 Na tomto místě opomíjím pluralistickou koncepci vztahu vnitrostátního, mezinárodního a evropského práva, která by $\mathrm{k}$ analýze dodala ještě další rozměry. Pro nastínění modelu horizontálního účinku postačí podle mého názoru analýza vnitrostátního právního řádu. 
V případě hodnocení právních systémů podle výše uvedených kritérií se jedná o modelový př́istup, nebot' reálně budou spíše nastávat situace smíšené, tedy př́ipady, kdy bude uznáváno více hodnot s relativně různými významy a zároveň o právním systému bude možno tvrdit, že jeho fragmentace je spíše dílčí a že usiluje o jednotu. ${ }^{42} \mathrm{Z}$ toho důvodu budu označovat za ideálně jednotný právní systém podobající se kelsenovské pyramidě. Diferencovaný právní systém bude programově obsahovat dělící linie mezi jednotlivými odvětvími, např́iklad v podobě ústředního postavení odvětvových právních principů a doktrín. V českém právním prostředí lze dále za prvek diferenciace označit ustanovení \1 odst. 2 občanského zákoníku, podle něhož uplatňování soukromého práva je nezávislé na uplatňování práva veřejného.

V právním řádu vyznačujícím se ideální jednotou práva a hierarchickým uspořádáním hodnot nebude horizontální účinek vyvolávat větší obtíže, nebot’ převáží vždy nejvyšší hodnota, která bude zároveň hodnotou v ústavním právu. Pokud se např́klad bude právní rád upírat $\mathrm{k}$ lidské důstojnosti, ta se stává trumfovou kartou $\mathrm{v}$ př́padě kolize s jakoukoliv jinou hodnotou nebo principem, at' už má původ v soukromém anebo v ústavním právu.

Situace se poněkud změní, pokud hierarchický hodnotový řád budeme spojovat s pohledem na právo jako na soubor dílčích subsystémů (budeme zdůrazňovat aspekt diferenciace oproti jednotě práva). $V$ takovém prrípadě musí rovněž zvítězit nejvyšší hodnota, k níž se právní ráa upírá, avšak ta se musí projevovat ve všech odvětvích práva a pouze v nich budeme daný prrípad řešit. Z toho vyplývá, že horizontální působení základních práv se neuplatní.

Aplikaci jednotlivých modelů můžeme ukázat na př́kladu bankovních poplatků, kde za základ vezměme výše uvedenou kauzu v České republice. V př́padě, že bychom se nacházeli v modelu hierarchického řádu hodnot, musíme identifikovat nejvyšší hodnotu, k níž se právo vztahuje. To samo o sobě může být předmětem sporu, pokud neexistuje např́iklad jednoznačné ústavní pravidlo („Stát X uznává hodnotu Y jako nejvyšší.“). Toto je však spíše akademický příklad, reálně se nevyskytující. Situace se však změní a zůstává otevřená různým interpretacím, pokud by ústavodárce do úvodního ustanovení vložil ochranu jediné hodnoty, která by v následné praxi byla chápána jako hodnota absolutní (srov. německou úpravu v čl. 1 Základního zákona: „Důstojnost člo-

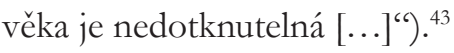

Pokud by nejvyšší hodnotou byla svoboda člověka, $\mathrm{v}$ prŕípadě přístupu $\mathrm{k}$ právu jako k hodnotově hierarchickému systému by byla autonomie vůle v právním jednání v soukromém právu projevem této nejvyšší ústavní hodnoty svobody. Z toho vyplývá, že by-

42 VAN DER KERCHHOVE, Michel, OST, Francois. Legal System between Order and Disorder. Oxford: Clarendon Press, 1994.

43 Čl. 1 odst. 1 první věta Základního zákona SRN. Ke sporu o absolutní či relativní povahu lidské důstojnosti viz výše pozn. pod čarou č. 22. 
chom museli akceptovat jakékoliv ujednání mezi klientem a bankou, pokud by bylo výrazem svobodné vůle. ${ }^{44}$ Obdobně při úvahách o této hodnotě v rámci diferencovaného pohledu na jednotlivá právní odvětví bychom argumentovali tak, že svoboda se projevuje $\mathrm{v}$ autonomii vưle $\mathrm{v}$ soukromém právu a tato hodnota na pozadí konfliktu s jakoukoliv jinou hodnotou v soukromém právu musí převážit. ${ }^{45}$ Aplikaci základních práv bychom nemuseli brát $\mathrm{v}$ potaz, nebot’ nejvyšší hodnota právního řádu se projevuje i v soukromém právu.

Pro pohled na systém hodnot jako na hierarchicky uspořádaný však nenalezneme v právních řádech současných států vesměs podporu; státy jsou naopak většinou popisovány jako pluralitní, jejichž hodnoty jsou nehierarchicky uspořádané. Této charakteristice odpovídají i ústavní úpravy, jakou je v České republice čl. 2 odst. 1 Listiny základních práv a svobod: „Stát je založen na demokratických hodnotách a nesmí se vázat ani na výlučnou ideologii, ani na náboženské vyznání. “46 Takovýto stav můžeme propojit jak s ideálně jednotným, tak s více diferencovaně uspořádaným právním systémem. Zatímco ohledně hodnotového systému moderního demokratického právního státu nepanují prriliš velké rozpory, poněkud odlišný se může zdát systémový pohled na právo. Z pohledu právních rádů, které se na území řady evropských států aplikují (právo vnitrostátní, mezinárodní a evropské), panuje vesměs přesvědčení o nehierarchickém uspořádání hodnot, které jsou právním řádem chráněny. Pohled na strukturu řady vnitrostátních právních řádů hovoří spíše o kombinaci systémových a protisystémových prvků. ${ }^{47}$

V situaci nehierarchického uspořádání hodnot a ideálně jednotného systému práva musíme provádět poměřování relevantních hodnot a principů, protože ani jeden z těchto standardů automaticky nepřeváží. Metodologie poměřování je v současné době hojně diskutovaným tématem právní teorie, na tomto místě však není možné se k ní vyjádřit podrobněji. ${ }^{48}$ Poměřování můžeme provádět v rovině zákonné úpravy anebo na vyšší,

$44 \mathrm{~V}$ prvé řadě by bylo nutné posoudit, zda se jedná o ujednání uzavřené svobodně. Následně, pokud by bylo takto posouzeno, by obsah ujednání nehrál roli.

$45 \mathrm{~K}$ ústavním zdrojům autonomie vůle, kterých je i podle judikatury Ústavního soudu ČR několik - čl. 1 odst. 1 Listiny základních práv a svobod vyhlášené usnesením předsednictva ČNR č. 2/1993 Sb., o vyhlášení Listiny základních práva a svobod jako součásti ústavního pořádku České republiky (v dalším textu jen „Listina základních práv a svobod“), který zní „lidé jsou svobodní a rovní v důstojnosti i v právech“, čl. 2 odst. 3 Listiny základních práv a svobod (zásada legální licence), čl. 11 Listiny základních práv a svobod (smluvní svoboda jako derivát ochrany vlastnického práva), viz HURDÍK, Jan, LAVICKÝ, Petr: op. cit., s. 83-85.

46 Čl. 2 odst. 1 Listiny základních práv a svobod.

47 RÖHL, Klaus, RÖHL, Hans Christian. op. cit., s. 451-454.

48 Můj pohled na tuto argumentační metodu je obsažen v př́íspěvku: ONDŘEJEK, Pavel. Poměřování jako klíčový argument přezkumu ústavnosti v éře proporcionality a některé projevy jeho kritiky. Právník, č. 4, 2016, s. 349-368. Př́spěvek navazuje na předchozí texty v rámci diskusní řady Proporcionalita v právu, která od listopadu 2015 vychází na stránkách časopisu Právník. Polemika s mým př́istupem je pak obsažena v navazujícím článku Jana Wintra: WINTR, Jan. Alexyho vážící formule..., s. 446-461. 
ústavní úrovni. Jednota systému vytvoří silný tlak na prozařování výsledků poměřování na ústavní úrovni do soukromého práva. Z tohoto důvodu postačí provést poměřování na ústavní úrovni a výsledek jednoduše promítnout do soukromého práva. Ve výše zmíněném př́padě bankovních poplatků bychom tedy poměřovali ústavní svobodu (v jejím projevu svobody právně jednat) s materiální rovností či spravedlností, která by vyžadovala $\mathrm{v}$ prrípadě faktické nerovnosti subjektů soukromoprávního vztahu určitá omezení silnější smluvní strany, v našem případě banky. Při realizaci tohoto poměřování by hrála roli řada faktorů, především míra faktického omezení svobody právního jednání v př́padě uzavírání smluv s bankami, faktické zatížení spotřebitelů bank jakožto důsledek nerovného postavení ve vztahu k bankám a v neposlední řadě i význam, jaký je v daném státě připisován hodnotám svobody a rovnosti. ${ }^{49}$

Poslední varianta spočívá v pohledu na diferencované právo prizmatem nehierarchicky uspořádaného systému hodnot, tedy hodnotového pluralismu bez absolutní preference nejvyšší hodnoty. V takové situaci se zdá být aplikace horizontálního účinku nejsložitější. Poměřování $\mathrm{v}$ jednom subsystému automaticky neodpovídá poměřování hodnot v jiném subsystému, nebot' tyto hodnoty se mohou lišit anebo se může lišit relativní preference v závislosti na kontextu. Do popredí proto vystupují pluralistické normativní teorie koherence, ${ }^{50}$ jež reflektují potřebu pohlîžet na právo jako na systém i s vědomím existence řady protisystémových elementů. ${ }^{51}$ Poměřování v takovém případě neprobíhá pouze v ústavním právu, nýbrž na úrovni ústavního i soukromého práva. Vzhledem k tomu, že neexistuje jednotný řád hodnot, mohou se výsledky, jichž jsme dosáhli v rámci jednotlivých odvětví, lišit. Pokud se tak děje, nastupuje horizontální působení, které by se mělo projevit tím, že v rámci soukromého práva vstoupí do poměřování určité ústavněprávní argumenty, které budou prozařovat do celého právního systému. Tyto ústavněprávní argumenty však na rozdíl od modelu jednotného právního systému nepředstavují trumfy v tom smyslu, že by automaticky převážily nad jakýmkoliv jiným argumentem. Je nutné uvažovat vztah veškerých principů a hodnot v soukromém právu k ústavněprávním

49 Výčet argumentů však není a ani nemůže být konečný, jak je podrobněji argumentováno jinde - srov. ONDŘEJEK, Pavel. Poměřování..., s. 366-367.

50 KRESS, Ken. Coherence. In: PATTERSON, Dennis (ed.). A Companion to Philosophy of Law and Legal Theory. Malden, Oxford: Blackwell Publishing, 1999, s. 533.

51 K heterarchickému uspořádání práva viz. WALKER, Neil: Beyond Boundary Disputes and Basic Grids: Mapping the Global Disorder of Normative Orders. International Journal of Constitutional Law. 2008, roč. 6, č. 3-4, s. 373-396, a v české literatuře řada textů J. Kysely - KYSELA, Jan. Měnící se struktura právního řádu a jeho atributy. Eric Stein Working Paper, č. 1/2009, dostupný na internetu: https://csesp. files.wordpress.com/2015/05/eswp-2009-01-kysela.pdf, KYSELA, Jan. Evropský konstitucionalismus: hierarchie, heterarchie a povídání mezi soudy. In: GÖT'TINGER, Vlastimil (ed.). Evropský konstitucionalismus v kontextu soudního dialogu. Brno: Ústavní soud, 2016, s. 100-111. 
hodnotám a principům. ${ }^{52}$ Pokud například v soukromém právu hraje vyšší roli princip autonomie vůle a v ústavním právu materiální rovnost, je potřeba výsledky kolizí v obou subsystémech uvést do souladu. Z důvodu vyšší právní síly musí ústavní právo ovlivňovat právo soukromé, nikoliv opačně. Tento vliv se může projevovat různě: první způsob spočívá ve vnesení určitých ústavních argumentů do řešení kolize soukromoprávních principů (např. svobodu jednat do soukromoprávní autonomie vưle, materiální rovnost a spravedlnost do ochrany spotřebitele, jakožto slabší smluvní strany). Dalším způsobem je nepřímé horizontální působení základních práv na výklad významů neurčitých pojmů obsažených v soukromém právu. Pojmy jako „dobrá víra“ nebo „dobré mravy“ mohou být vyloženy způsobem, který zohledňuje ústavněprávní hodnoty. Právně jednat proti dobrým mravưm může například ten, kdo zachází s člověkem pouze jako s objektem (čímž omezuje jeho důstojnost). ${ }^{53} \mathrm{Na}$ druhou stranu, jakékoliv subjektivně pocit'ované limitování svobody jednat nemůže být označeno pouze z tohoto důvodu za jednání proti dobrým mravům.

Pro ilustraci se pokusím výše nastíněné přístupy shrnout do přehlednější tabulky:

\begin{tabular}{|c|c|c|}
\hline & ideální jednota práva & diferenciace práva \\
\hline $\begin{array}{l}\text { hierarchický řád } \\
\text { hodnot }\end{array}$ & $\begin{array}{l}\text { nejvyšši hodnota převáží v ústav- } \\
\text { ním právu, případ z důvodu hodno- } \\
\text { tové i systémové koherence nebude } \\
\text { vzbuzovat obtíže }\end{array}$ & $\begin{array}{l}\text { nejvyšší hodnota převáží, řešíme } \\
\text { v rámci relevantního subsystému } \\
\text { práva, argument horizontálním pů- } \\
\text { sobením se nepoužije }\end{array}$ \\
\hline $\begin{array}{l}\text { nehierarchické } \\
\text { uspořádání hodnot }\end{array}$ & $\begin{array}{l}\text { provádíme poměřování pouze } \\
\text { na úrovni ústavního práva a apliku- } \\
\text { jeme prozařování ústavních hodnot } \\
\text { a principů }\end{array}$ & $\begin{array}{l}\text { provádíme poměřování na úrov- } \\
\text { ni ústavního i soukromého práva } \\
\text { a porovnáváme výsledky, horizon- } \\
\text { tální působení uplatňujeme při po- } \\
\text { měřování v soukromém právu }\end{array}$ \\
\hline
\end{tabular}

\section{Závěr}

Příspěvek se pokouší pohližet na problematiku horizontálních účinkủ základních práv optikou konfliktu principů a hodnot ústavního a soukromého práva. Tyto principy a hodnoty tvoří základ právních odvětví a řešení jejich konfliktů není v právním řádu apriorně stanoveno. Východiskem pro zkoumání vztahu základních práv a autonomie

$52 \mathrm{~K}$ tomu je potřeba doplnit, že i pokud by v konečném důsledku ústavně konformní interpretace nebyla možná, ústavní principy stále mohou být důvodem zásahu Ústavního soudu, pokud by soukromoprávní úprava nebyla kompatibilní s ústavou.

53 K „formuli objektu“ srov. podrobně: MAHLMANN, Matthias. Elemente einer ethischen Grundrechtstheorie. Baden Baden: Nomos, 2005, s. 101 a násl. odkazující zejména na dílo G. Düriga, který je autorem této koncepce (např. DÜRIG, Günter. Die Menschenauffassung des Grundgesetzes. Juristische Rundschau. 1952, s. 259 a násl.). V české literatuře srov. komentář J. Baroše k článku 1 Listiny základních práv a svobod v: WAGNEROVÁ, Eliška a kol. Listina qákladních práv a svobod. Komentár. Praha: Wolters Kluwer, 2012, s. 58. 
vưle v právním jednání v soukromém právu je potřeba systémového přístupu a zkoumání práva ve dvou rovinách: na abstraktnější úrovni jde o posouzení systematiky hodnot, v konkrétnější rovině o hodnocení systémových a protisystémových prvků v právu. Právě při zkoumání horizontálního působení základních práv se ukazuje, ${ }^{54}$ že různé pohledy na tuto problematiku jsou dány především hodnocením výše uvedených systémových otázek.

Přestože projevy autonomie vůle v soukromém právu můžeme nalézt v ústavních hodnotách svobody a důstojnosti člověka, ${ }^{55}$ nelze podle mého názoru na zdroje soukromoprávních principů a lidských práv pohlížet, jako by měly stejný základ. ${ }^{56}$ Ostatně bylo to právě soukromé právo, které plnilo po dlouhou dobu funkci tehdy neexistující ústavní úpravy. Je tedy otázkou, zda poválečný ústavní vývoj zdůrazňující „prozařování“ objektivního řádu hodnot složeného ze základních prá $v^{57}$ mohl vyloučit či proměnit po staletí utvářené soukromoprávní zásady. Pokud by tomu tak bylo, museli bychom na soukromé právo, ale i na další právní odvětví pohlížet pouze jako na jakési „aplikované právo ústavní", čímž bychom značně limitovali význam specifických odvětvových právních principů a konečně i samotných zákonů.

Právní řády moderních států nelze hodnotit jako směřující k naplnění jediné ústřední hodnoty. Hodnotový pluralismus a absence hierarchie hodnot nutně vyžaduje poměřování principů a hodnot jako způsob řešení jejich kolizí. Poměřování tedy představuje první východisko aplikace horizontálního působení základních práv. Na otázku, na jaké úrovni poměřování provést, odpovídá zhodnocení systémových ale i protisystémových elementů v současném právu. Právní rády moderních států se nepodobají ideální pyramidě, působí $v$ nich řada zdrojů diferenciace, někdy dokonce fragmentace. To platí přirozeně za situace souběžného působení práva vnitrostátního, mezinárodního a evropského, ale také v samotném právu vnitrostátním. Zde lze spatřovat určité rysy oslabování jednoty systému. Na druhé straně však autonomie právních odvětví musí být limitována, aby právní systém nebyl prŕliš fragmentovaný.

Pohled na současné právo jako na systém diferencovaný a nevážící se na jednu absolutní hodnotu, avšak zároveň jako na systém, jež nerezignuje na vnitřní strukturu a usilující rovněž o koherenci, naznačuje, že v př́padě horizontálního působení základních práv jde zejména o nepřímý účinek. Konkrétní výsledek je pak nejvíce ovlivněn poměřováním na ústavní úrovni, které současně ovlivňuje konflikt soukromoprávních principů. Dů-

54 Analýzu několika př́padů z oblasti právního jednání právnických osob jsem představil v příspěvku: ONDŘEJEK, Pavel. Konstitucionalizace soukromého práva na př́kladu limitů právního jednání právnických osob. Jurisprudence, 2016, roč. 25, č. 3, s. 32-41.

55 BARTOŇ, Michal, KRATOCHVÍL, Jan, KOPA, Martin, TOMOSZEK, Maxim, JIRÁSEK, Jiří, SVAČEK, Ondřej. Základnípráva. Praha: Leges, 2016, s. 56.

56 Opačný názor zastává M. Bartoň v díle citovaném v předchozí poznámce pod čarou.

57 Rozhodnutí Spolkového ústavního soudu SRN ve věci „Lüth“ ze dne 15. ledna 1958 (BVerfGE 7, 198). 
sledkem toho, že právní řád není zcela jednotný, ani zcela diferencovaný či fragmentovaný, je pak potřeba zohledňování specifik právního jednání v soukromém právu při úvahách o horizontálních účincích základních práv. Tímto způsobem posoudil, podle mého názoru správně, Ústavní soud České republiky kauzu ústavnosti bankovních poplatků. 